\title{
病院待合室の音環境に関する研究 \\ A STUDY ON ACOUSTIC ENVIRONMENT AT WAITING AREAS IN HOSPITALS
}

\author{
豊増 美 喜*1, 大鶴 徹*2, 内之浦 祐樹*3, 岡 本 則 子*4, 富 来 礼 次*5 \\ Miki TOYOMASU, Toru OTSURU, Yunki UCHINOURA, \\ Noriko OKAMOTO and Reiji TOMIKU
}

\begin{abstract}
A series of measurements of sound pressure levels were carried out at waiting areas in hospitals; meanwhile, psychoacoustical survey questionnaires were conducted. Measurements of impulse responses were also carried out to extract reverberation time $\left(T_{20}\right)$. As a result, the relationship between the $L_{\mathrm{Aeq}}$ and questionnaires reveals the statistical tendency that the subjective perception of acoustic condition turns to "bad" from "good" at the $60 \mathrm{~dB}$. The comparison of $T_{20}$ and the average absorption coefficients $(\bar{\alpha})$ for waiting areas offer the hypothesis that the difference in ceiling absorption coefficients influences architectural acoustic condition.
\end{abstract}

Keywords: hospital, waiting area, sound environment, sound pressure level, questionnaire 病院, 待合室, 音環境, 騒音レベル,アンケート

1. はじめに

1.1. 背景と目的

アメニティや撚しの環境への関心が高まる中、医療施設における 音環境は、今後重要視されていくと思われる。また、1995年の厚生 白書"では、国民のほぼ6割が医療をサービス業ととらえているとい う実態が示され、1997年の同白書”湟療の質の確保・改善の立場 から、技術評価と共に、医療の「質の評価」が重要性を增している としている。医療の「貿の評価」は、個別技術のみならず、施設設 備・人員・体制などが総体となって提供される医療サービスを患者 側から全体的に評価するものとされる。筆者らは、医療の質の善し 悪しに及ぼす医療施設の音環境の影響が無視できないものと考元 る。即ち、患者や家族などの同伴者（以下、利用者と表す）に良質 な医療サービスを確保するため、医療施設の音環境も、利用者の評 価から改善を検討するべきである。

病院の部門は大きく「病棟」「外来部」「診療部門」「供給部 門」「管理部」の5部門に分けられる3》。「外来部」に属する待合室 は、病院各部門の利用者の多くが滞在、通過する場である。また日 本では、戦後の医療機関の中央化や大病院指向によって、利用者が 総合病院へ集中し、待合室で長い時間を過ごしていると言われてい る4-6)。公共公益施設である病院の待合室には、多数の人が出入り し、人の声や動作音、機械音に加え、絶え間ないアナウンス音の報
告》もあり、多くの音が存在している。この状況は、利用者にとって 好ましくない音環境であると考えられる。

病院の音環境に関する既往の研究で、ICUを含む病棟部門の音環 境を対象としたものは、過去に国内外で行われており、例えば国内 では、Kuwano に含む研究は、山田らによる内部発生音の調査 ${ }^{101}$ 、上原による外 来ロビーの音環境調査 ${ }^{11}$ があるものの、待合室の騒音レベルの連絸 測定、アンケート調查、及び改善策など対策手法の効果について、 未だ十分に報告はされていない。

そこで本研究では、待合室の音環境の実熊を調査し、その問題点 と、建築音響的な対策手法の効果を明らかにすることを目的とす る。まず䭷音の時間変動の実態を把握するため、待合室で騒音レべ ルの連続測定を行う。続いて、待合室の利用者が、室内の音環境を どのように捉えているかを把握するためのアンケート調査を行う。 さらに、待合室で働く看護師・事務職員等（以下、スタッフと表 す）に対しても、利用者とスタッフを比較し回答の傾向を見るため にアンケート調查を行う。最後に、待合室における建築音響的な对 策手法の一端として、天井仕上げ材の变更による効果を検討した。

\section{2 調查対象}

騒音レベル及びインパルス応答の測定対象は、3病院の待合室7室
*1 大分大学大学院工学研究科環境工学専攻博士後期課程 大学院生

*2 大分大学工学部福祉環境工学科建築コース 教授・エ博

*3 株)インクス 修士(工学)

*4 大分大学大学院工学研究科環境工学専攻博士後期課程 大学院生・修士 (工学)

*5 大分大学 VBL 研究員 $\cdot$ 博士 (工学)
Graduate Student, Graduate School of Eng., Oita Univ.

Prof., Dept. of Architecture, Faculty of Eng., Oita Univ., Dr. Eng.

INCS Inc., M. Eng.

Graduate Student, Graduate School of Eng., Oita Univ., M. Eng.

P.D. Research Fellow, Venture Business Laboratory, Oita Univ., Ph. D. 
表1 測定対爱病院の概要

\begin{tabular}{|c|c|c|c|}
\hline & 病院 & S病院 & SS病院 \\
\hline 所在 & $m$ & 福同県 & 侮问 \\
\hline 開院時期 & 987年7月 & 1997年12月 & 2000年10月 \\
\hline & RC 6階建 & SRC 2階建 & SRC 8階建 \\
\hline & 250 & 149 & \\
\hline 診竂時間 午亩 & $9: 00-12$ & 9:00-12:00 & 9:00-12:00 \\
\hline $\begin{array}{c}\text { 午後 } \\
\text { （日祝は休診） }\end{array}$ & \multicolumn{3}{|c|}{ (3病院共、解急患者は24時間受付) } \\
\hline
\end{tabular}

表 2 待合室の利用時間帯

庤合室 利用時間帯

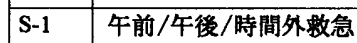

W-1 午前/午後/時間外救急

SS-1 午前/午後

SS-2 午前/午後 (一部)

W-2 午前/午後 (一部)

W-3 午前/午後 (一部) SS-3 午前/午後
表 3 待合室の内装仕上げ材

\begin{tabular}{|c|c|c|c|}
\hline 待合室 & 天井 & 垶 & 床 \\
\hline S-1 & 岩綿吸音板 & ビニル垶紙 & プラスチックタイル \\
\hline W-1 & 岩綿吸音板 & ビニル塈紙 & プラスチックタイル \\
\hline SS-1 & 岩綿吸音板 & 紙壁紙 & 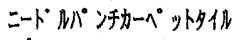 \\
\hline SS-2 & $\begin{array}{l}\text { 岩綿吸音板 } \\
\text { 及び天空 }\end{array}$ & 紙壁紙 & プラスチックタイル \\
\hline W-2 & 岩綿吸音板 & ピニル暨紙 & 塩化ビニールシート \\
\hline W-3 & 化粧石高ボード & ビニル壁紙 & 塩化ビニールシート \\
\hline SS-3 & $\begin{array}{l}\text { 岩綿吸音板 } \\
\text { 及び天㥶 }\end{array}$ & 紙壁紙 & プラスチックタイル \\
\hline
\end{tabular}

圆

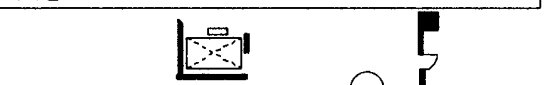

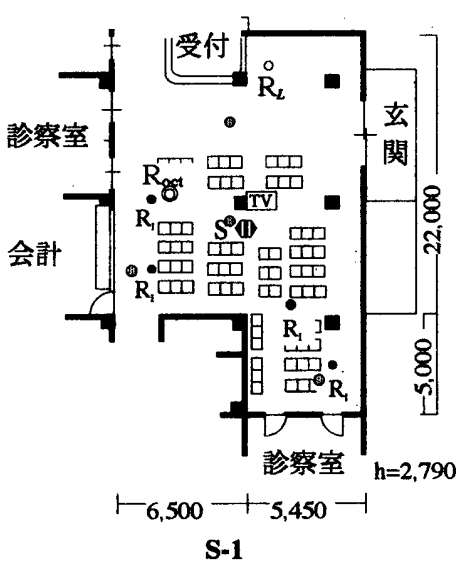

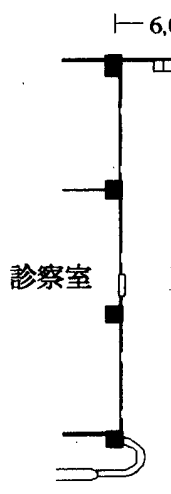

$\vdash 6.000+6,000-1$

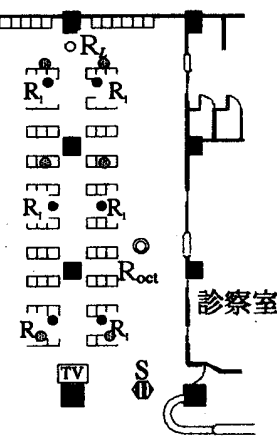

SS-2

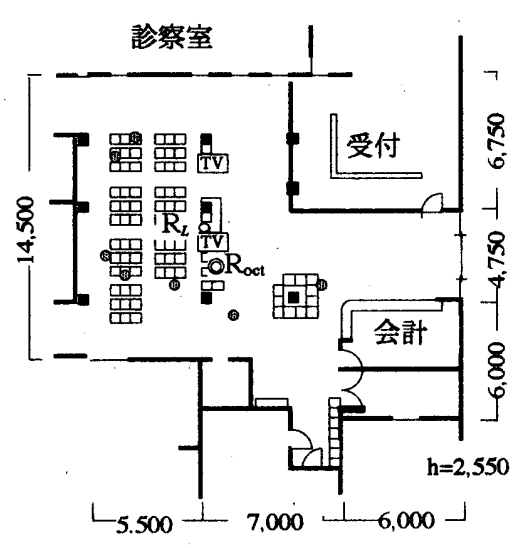

W-1

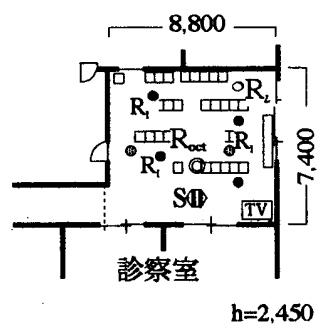

W-2

$0 \quad 5,000 \quad 10,000(\mathrm{~mm})$

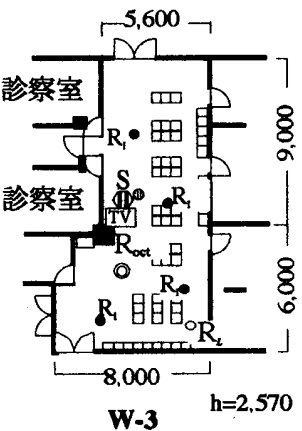

$-6,000+6,000+6,000-^{h=3,550}$

SS-1

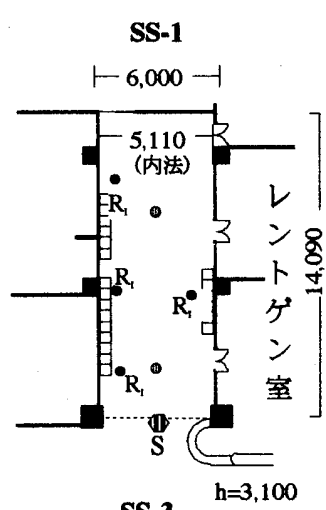

SS-3

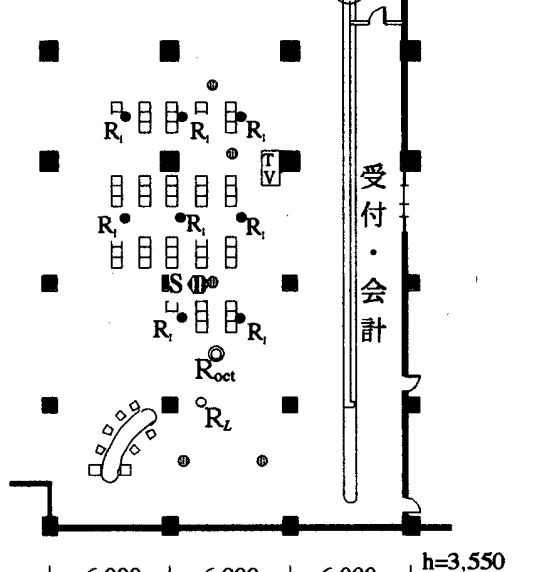

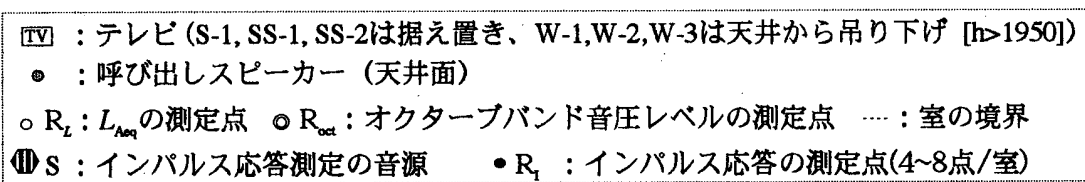

図1調查対象待合室の平面図

から選定したそれぞれ6室とする。測定対象病院の概要を表1に、待 合室7室の利用時間帯を表2に、内装仕上げ材を表3に、平面図を図1 にそれぞれ示す。待合室S-1、W-1は受付・会計・診療待ちに、SS-1 は受付・会計待ちに、W-2、W-3、SS-2は診療待ちに、SS-3はレン トゲンの検査待ちに、それぞれ使われている。なお、測定した全て の待合室で測定時にBGMは流されていないことを確詔している。

アンケート調査対象の概要は、3章で述べる。

\section{2. 騒音レベルの時間变動}

\section{1 测定の概要}

各待合室内の騒音レベルの時間変動を把握するため、待合室の 15 分間の等価騒音レベル $L_{\text {Aeq, } 1 \text { min }}$ の連続測定を行う。なお本章の測定で は、1章に示す調査対象のうち、レントゲンの検查待ちに使われ利用 者の少ないSS-3を除いた待合室6室を対象としている。測定にはサウ ンドレベルメータ（RION：NL-14、NL-06）を用い、4日間から6日 間の自動計測の結果を検討に用いる。図1の各待合室の平面図に、測 定点 $\mathrm{R}_{L}$ （床上 $1.2 \mathrm{~m}$ ）を示す。サウンドレベルメータの設置場所は、 図 1 に示すテレビ（各室共、診療時間についている）や呼び出しス 
表4 各待合室の昼間及び夜間の $L_{\text {Aea }}$

\begin{tabular}{|c|c|c|c|c|c|c|c|}
\hline \multirow{2}{*}{ 時間の区分 } & \multirow{2}{*}{$\begin{array}{l}\text { 騒音影響に関する } \\
\text { 室内指針 }\end{array}$} & \multicolumn{6}{|c|}{ 各待合室の $L_{\mathrm{Aeq}}[\mathrm{dB}]$} \\
\hline & & S-1 & W-1 & SS-1 & SS-2 & $\mathrm{W}-2$ & W-3 \\
\hline 昼間( & 45dB以下 & 59.4 & 61.0 & 53.2 & 52.1 & 52.6 & 51.5 \\
\hline 夜間(22時-6日 & 35dB以下 & 48.1 & 52.2 & 42.0 & 44.7 & 37.4 & 37.7 \\
\hline
\end{tabular}
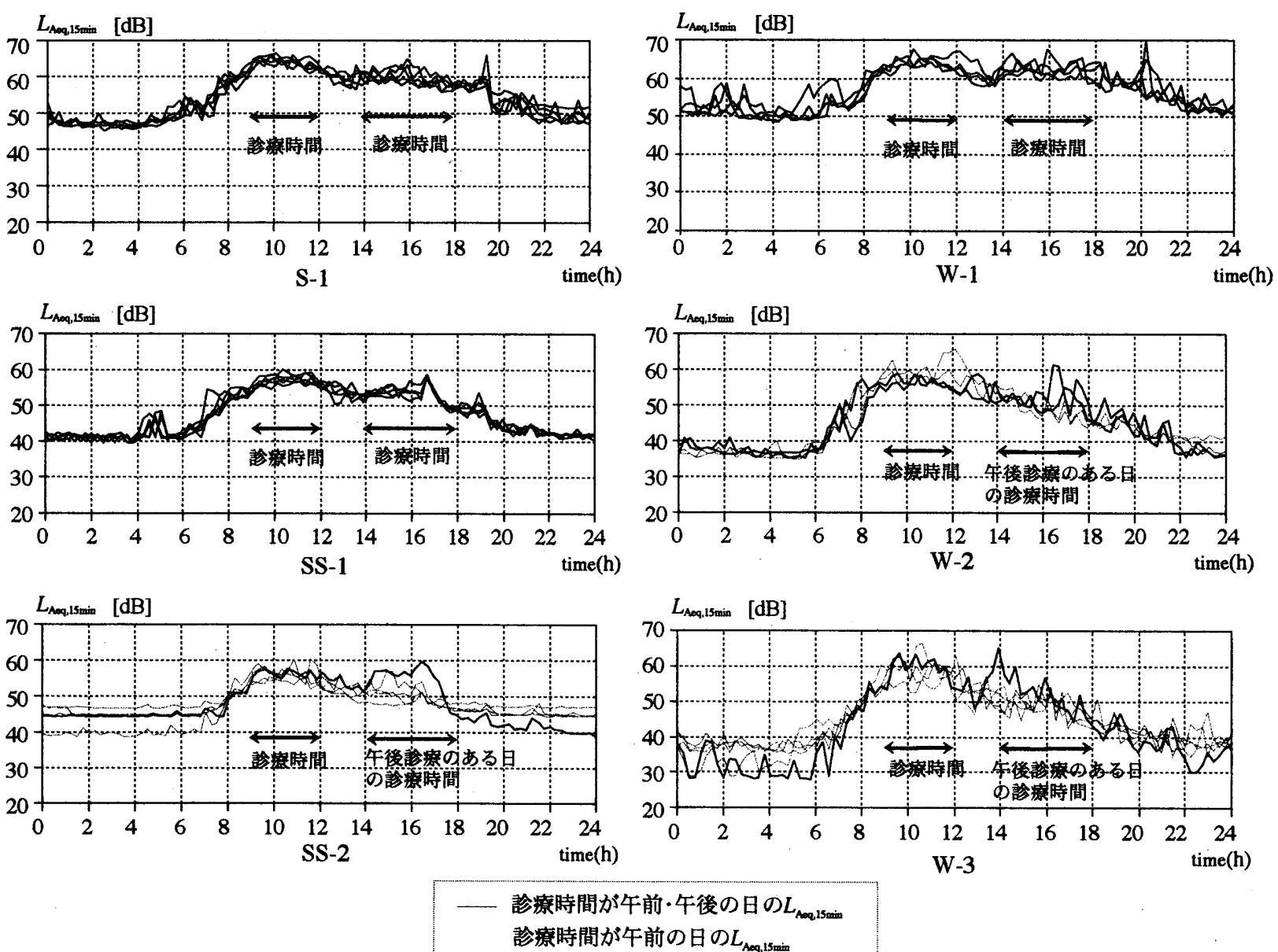

図2 各待合室における診療日の $L_{\text {Aeq, } 1 \text { m min }}$ の変動

ピーカーなどからの音の直接的な影響を受けにくく、利用者とス タッフの動線上を避け、できるだけ室の騒音を代表する位置である ことを考慮し決定する。

\section{2 結果及び考察}

測定された室の騒音レベルをふまえて室の音環境の改善を検討す るには、室内騒音の許容値や指針值等との比較が必要となる。 Kuwanoらは、前揭の病棟を測定対象とした研究のの中で、测定した 騒音レベルと、騒音に係る環境基準の改訂の基礎となった答申「騒

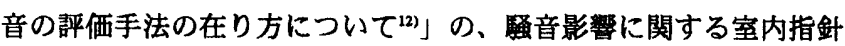
とを比較している。

しかし、病院の待合室のように、多数の人が出入りし、その利用 者が同時に騒音の発生者となる、公共公益施設の室内における变動 騒音の許容值や指針値は明確に示されていない。筆者らは、次のよ うに考える。即ち、騒音影響に関する室内指針は、基本的には室内 に存在する音については考慮されていない。しかし「人の健康を保 護し、及び生活環境を保全する上で維持されることが望ましい基淮
13)」が環境基準である、とする理念をふまえるならば、病院の待合 室における䣫音レベルの指針值としての妥当性もありえる。そこで 本研究では、測定した騒音レベルと、騒音影響に関する室内指針と を比較する。

騒音影響に関する室内指針との比較のため、測定期間内の診療日

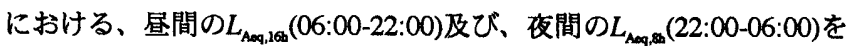
各待合室ごとに求める。結果を表4に示す。特に静穞を要する地域が 含まれる「一般地域」の騥音影響に関する室内指針は「昼間 : $45 \mathrm{~dB}$ 以下、夜間 : $35 \mathrm{~dB}$ 以下」であり、この室内指針を全ての待合室で上 回っている。また、待合室ごとの差は、昼間より夜間の方が大き く、W-1とW-2の間では約15dBの差が生じている。これは、夜間は 救急外来の待合に使用している室(S-1,W-1)と、救急外来の待合に使 用されずほとんど在室者のいない室(SS-1,SS-2,W-2,W-3)との違いに よるものと考えられる。

次に、各待合室における、診療日の時間及び日による騷音レベル の違いを見ることを目的とし、 $L_{\text {Aeq, } 1 \text { 年的 }}$ の変動を図2に示す。 
$L_{\text {Aeq,15min }}$ の変動には、診療時間に対応した以下のような変動がみら れる。まず各待合室に共通して、午前の診療時間である9時前後か ら12時前後が、1日の中で $L_{\text {A } \mathrm{Aq}, 15 \min }$ の高い時間帯である。また、曜日を 問わず午後にも利用されるS-1、W-1及びSS-1は、午後の診療時間の 14時前後から 18 時前後の間に、再び $L_{\text {Aeq, } 15 \min }$ が高い時間帯がある。曜 日によって午後にも利用されるW-2、W-3及びSS-2は、午後の診療 のある日に同様の変動がみられる。さらに、夜間に救急外来の待合 に利用しているS-1,W-1の $L_{\text {Aeq, } 15 \text { min }}$ は、他の待合室と比べ、18時の診療 時間終了後も大きくは下がらない。このように $L_{\text {Aeq, }, 15 \min }$ の変動は、診
療時間に関連した待合室の利用時間帯との関係が大きいことがわか る。

3. 利用者とスタッフに対するアンケート調查

\section{1 調查の概要}

待合室の利用者、及び待合室で呼出業務を行っているスタッフを 対象に、音環境に対する意識のアンケート調查を行なう。利用者の アンケートは2章の測定対象と同じ待合室6室で、調査員が待合室内 で配布、回収する。スタッフのアンケートは、2章の測定対象だけで

表5 利用者を対象としたアンケート調査の概要

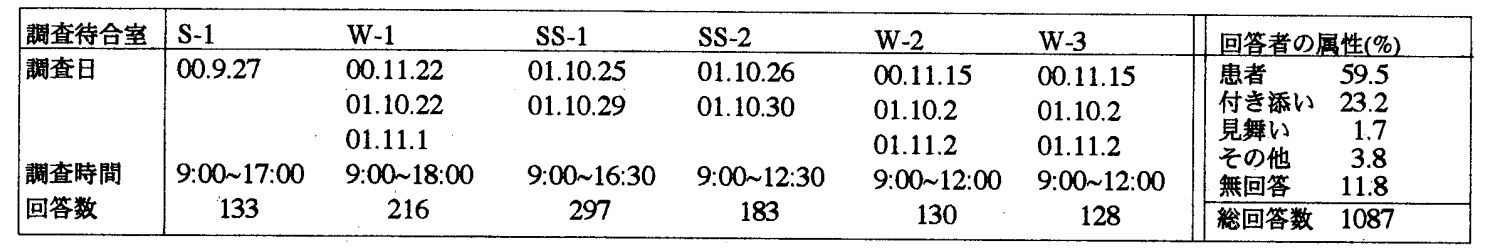

表6 スタッフを対象としたアンケート調査の概要

\begin{tabular}{|l|l||lr|}
\hline 調查病院数 & 11 & 回答者の属性 $(\%)$ \\
\cline { 3 - 4 } 調査日 & $01.10 .30 \sim$ & 事務職員 & 61.8 \\
& 01.11 .17 & 看護師 & 29.2 \\
配布数 & 280 & そ他 & 7.9 \\
回収数 & 178 & 無回答 & 1.1 \\
\cline { 3 - 4 } 回収率(\%) & 63.6 & 総回答数 & 178 \\
\hline
\end{tabular}

表7 アンケート設問項目

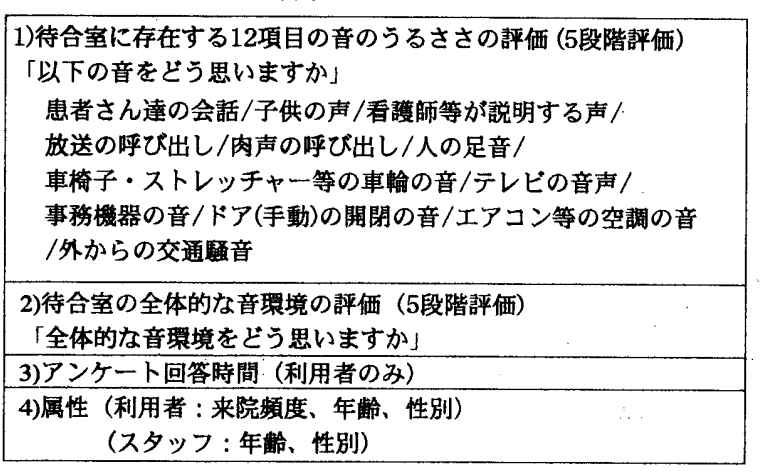

表8 待合室に存在する音の $L_{\text {Amax }}$

\begin{tabular}{|c|c|c|c|}
\hline 音 & $\begin{array}{c}L_{\text {atum }} \\
\text { 算術 } \\
\text { 平均 } \\
\end{array}$ & $\begin{array}{c}(\mathrm{dB}) \\
\text { 最大值 }\end{array}$ & $\begin{array}{l}\text { 淍定 } \\
\text { 回数 }\end{array}$ \\
\hline 患者さん達の会話 & 66.6 & 75.9 & 8 \\
\hline 子供の声 & 85.9 & 87.2 & 3 \\
\hline 看権師等が説明する声 & 65.2 & 70.3 & 5 \\
\hline 放送の呼び出し & 75.5 & 82.2 & 12 \\
\hline 肉声の呼び出し & 72.6 & 83.6 & 10 \\
\hline 車椅子・ストレッチャ一等の車輪の音 & 61.8 & 64.8 & 2 \\
\hline テレビの音声 & 66.0 & 72.2 & 9 \\
\hline ドア(手動)の開閉の音 & 69.6 & 73.5 & 8 \\
\hline
\end{tabular}

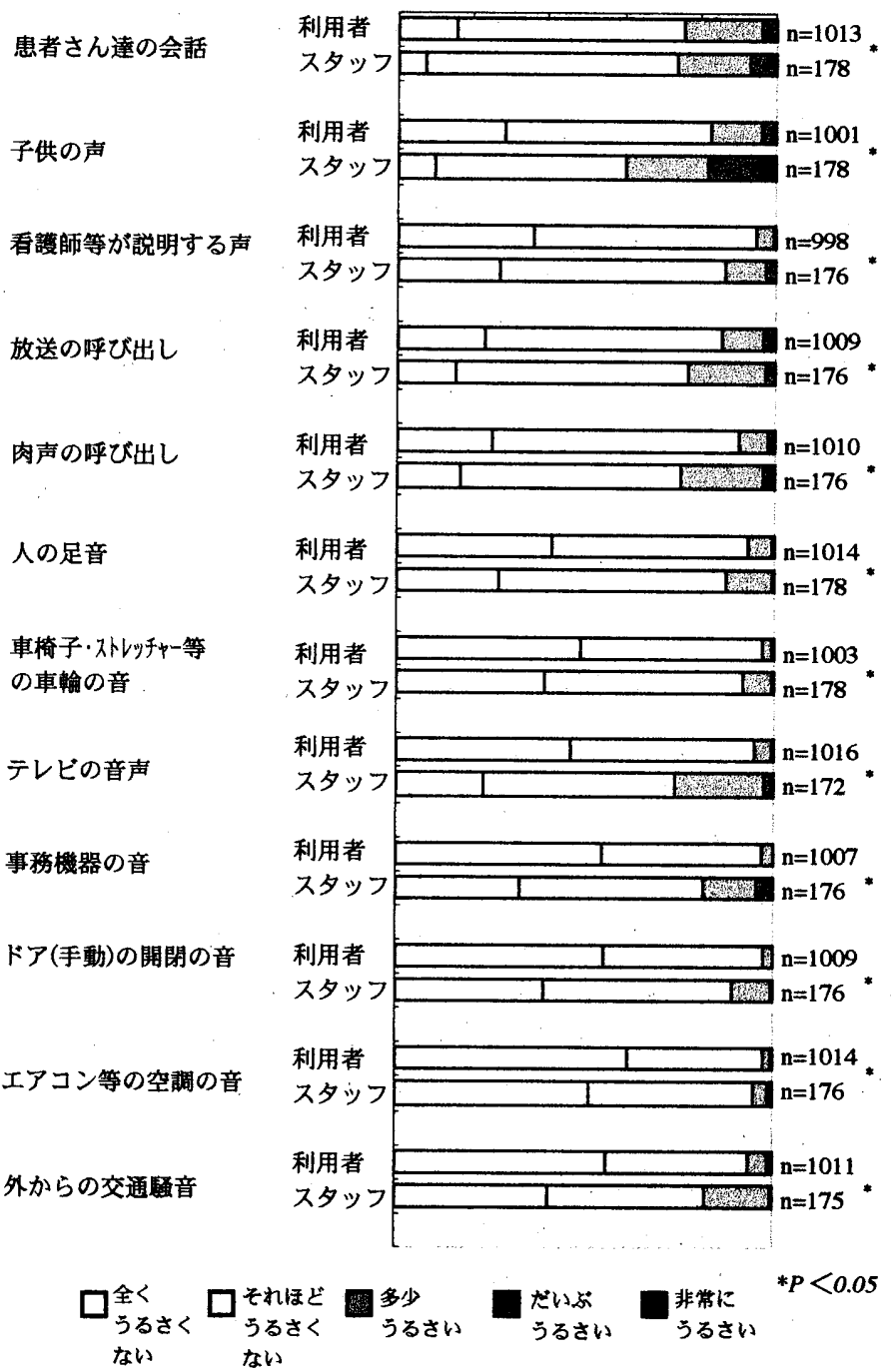

図3：各音に対する利用者とスタッフの評価 （nはサンプル数） 
は検討に十分な回答数を確保できないことから、11の総合病院を調 查対象とし、留置法とする。利用者を対象としたアンケート調査の 概要を表5に、スタッフを对象としたアンケート調査の概要を表6に 示す。

アンケートの設問項目を表7に示す。利用者には、アンケート実 施時に在室している待合室について、スタッフには、普段最も頻繁 に働いている待合室についての回答を依頼する。まず、事前に行 なった予備調査結果をふまえ、調查対象の全待合室に共通して存在 する12項目の音のうるささに関し、評価を求める。この評価には、 矢野らにより提案されている、うるささの標準尺度 ${ }^{14)}$ (5段階評価） を用いている。次に、全体的な音環境の評価を求める。この評価に は、評価語に「良い-悪い」を用い、5段階評価とする。さらに、利 用者の全体的な音環境の評価と、 $L_{\text {A乎 }}$ との関係の調査を目的に、アン ケートの調查時間内に、困1の測定点 $\mathrm{R}_{L}$ で10分間の等価騒音レベル $L_{\text {Aeq,10min }}$ を測定する。利用者のアンケートでは、全体的な音環境の評 価の設問の次に回答時間の設問を設け、記述された回答時間を含む $L_{\text {Na, } 10 \text { min }}$ をアンケート回答時の $L_{\text {Aeq, } 10 \text { min }}$ とし、検討に用いる。 3.2 12項目の音に対する評価
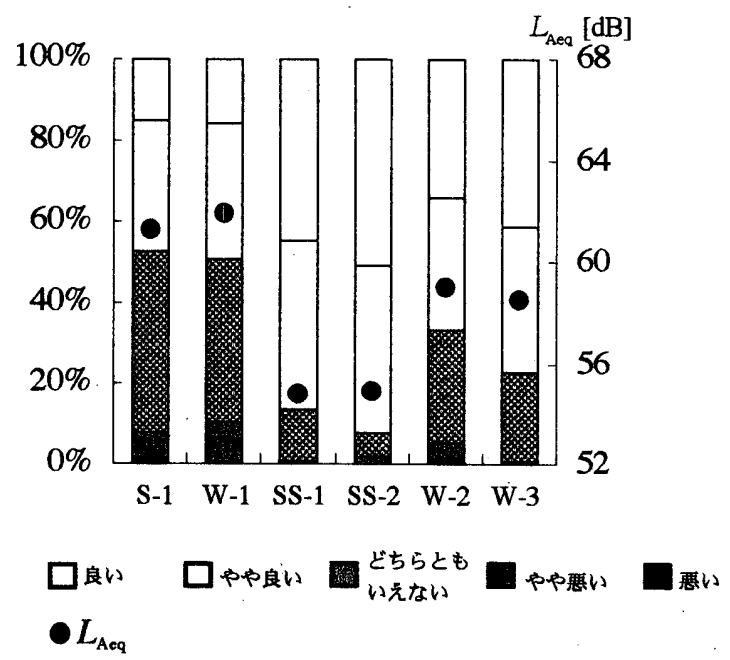

図4 各待合室別の全体的な音環境の評価の割合と アンケート調査時間の $L_{\text {Aded }}$

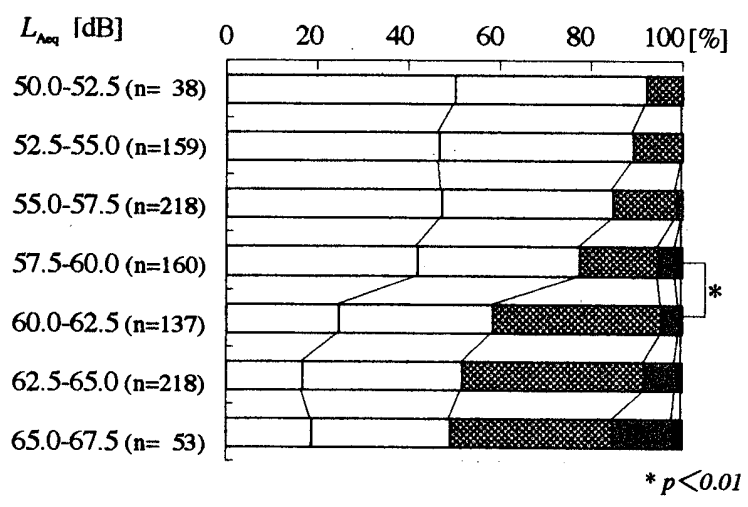

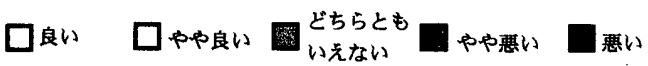

図5利用者の全体的な音環境の評価と アンケート回答時の $L_{\text {Aeq }}$ との関俰
病院の待合室のような公共公益施設の室内空間では、室内に存在 する各音の騒音レベルの測定に際して十分なS/N比の確保が困難な場 合がある。今回の調査では、現場で測定者が測定可能と判断した音 の $L_{\text {Amax }}$ を各音から約 $1 \mathrm{~m}$ 点で測定する。 $L_{\mathrm{A} \max }$ の算術平均値、最大值、 及び測定回数を、参考値として表8に示す。 $L_{\mathrm{Amax}}$ の高い音は「子供の 声」「肉声の呼び出し」「放送の呼び出し」で、最大値が80dBを越 えている。

次に、各音に対するうるささに関する評価を、利用者とスタッフ とに分け図3に示す。「非常にうるさい」「だいぶうるさい」「多少 うるさい」のカテゴリーを併合して『うるさい』のカテゴリーとし た場合、利用者が『うるさい』と感じる音は、「患者さん達の会 話」が24.6\%と最も高く、次は「子供の声」の17.5\%である。一方、 スタッフでは、「子供の声」が39.9\%と最も高く、次は「患者さん 達の会話」の $26.4 \%$ である。他の音と比較して、利用者・スタッフ 共に、利用者から発せられる声をうるさいと回答する割合が高い。

また、利用者とスタッフの回答結果を比較すると、各音に対して 『うるさい』のカテゴリーの割合は、すべての音で、利用者に比べ スタッフが多い。各音ごとの利用者とスタッフの回答結果につい て、帰無仮説を「利用者とスタッフで、うるささに関する評価の割

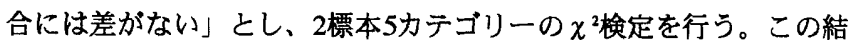
果、すべての音で、有意水準5\%で帰無仮説が㶳却される。以上より 筆者らは、利用者とスタッフのうるささに関する評価の割合には、 差があると判断した。

\section{3 利用者の音環境の言価と $\boldsymbol{L}_{\text {Aeq }}$ との関係}

利用者の全体的な音環境の評価と、各待合室のアンケート実施時 間内の $L_{\text {Aeq }}$ を各待合室ごとに図 4 に示す。アンケート実施時間に $L_{\text {A aq }}$ の 高い待合室は評価が低い。

図5に、利用者の全体的な音環境の評価と、アンケート回答時の $L_{\text {Aeq }}$ との関係を示す。 $L_{\text {Aeq }}$ が高いと利用者の音環境の評価が低くなる 傾向がみられ、「悪い」「やや悪い」のカテゴリーを併合して『悪 い評価』のカテゴリーとした場合、55.0dB未満の 2 つのグループで は『悪い評価』の回答はみられない。一方、「良い」「やや银い」 のカテゴリーを併合して『良い評価』のカテゴリーとした場合、 $57.5 \mathrm{~dB}$ 以上 $60.0 \mathrm{~dB}$ 未満のグループの『良い評価』の回答の合計が77 \%であるのに対し、60.0dB以上62.5dB未満のグループでは $58 \%$ 差 が大きい。

次に、 $L_{\text {Aeq }}$ の値の範囲が隣り合うグループ間について、それぞれ2 標本5カテゴリーの $\chi^{2}$ 検定を行う。その結果、帰無仮説を「 $57.5 \mathrm{~dB}$ 以上 $60.0 \mathrm{~dB}$ 未満と60.0dB以上 $62.5 \mathrm{~dB}$ 未満のグループ間で、全体的な 音環境の評価の割合に差はない」とした検定のみ、有意水饬1\%で帰 無仮説が葉却される。また、その他の隣り合うグループ間の検定で 㷌無仮説は㶳却されない。以上より筆者らは、利用者の音環境の評 価は、 $L_{\text {Aeq }}$ が60dB付近に差があると判断した。図4の各待合室別の評 価を比較すると、評価の悪いS-1、W-1の2室のアンケート実施時間 内の $L_{\text {Aeq }}$ は60dBを超えており、『良い評価』はこの 2 室のみ $50 \%$ \% 回っている。

4. 待合室の建策音響的な対策手法に関する検討

4.1 天井仕上げ材の傾向 
前章て、待合室における音環境の現状として、騒音レベルの時間 変動と、利用者及びスタッフの音環境に対する意識の一端を明らか にした。

本章では、待合室における建築音響的な対策手法の一端として、 室の境界条件の変更による音環境の改善効果を検討する。以前より 病院設計において、内部発生音に関して天井面の吸音材での対処が 推奖されているが15)、本研究でも待合室の境界条件のうち比較的容 易に変更可能となる天井仕上げ材を検討の対象とする。

待合室における天井仕上げ材の使用の傾向をみるため、雑誌「医 院建築」に揭載された過去9年間（1995-2003） ${ }^{162-24)}$ の病院・医院建築

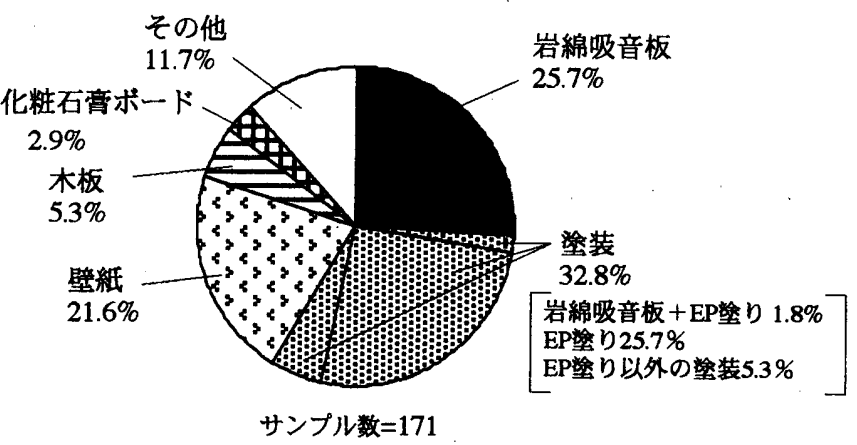

図6 待合室の天井仕上げ材の割合
の、待合室で施工された天井仕上げ材の割合を集計し、参考として 図6に示す。岩綿吸音板の比率は25.7\%で垐装に次いで高いが、汪装 を含め他の天井仕上げ材は吸音率の低い材である。

\section{2 测定手法・概要}

天井仕上げ材に岩綿吸音板を施工した室と、化精石䡒ボードを施 エした室との比較のため、インパルス応答の測定を行う。インパル ス応答の測定結果から、ISO3382 ${ }^{25}$ に準じて、インパルス応答2乗積 分法における最小2乗近似直楾の回帰範囲を-5〜-25dBとしたときの 残響時間（以下、 $T_{20}$ と表す）を算出し、天井仕上げ材の変更による 効果の検討に用いる。

まず、付随して、待合室6室における、診療時間内のオクターブバ ンド音圧レベルを測定した。なお、このオクターブバンド音圧レベ ルは、図1の測定点 $\mathrm{R}_{\mathrm{oct}}$ で測定され、5分間のエネルギー平均値とし た。結果を図7に示す。

図7より、待合室の診療時間内のオクターブバンド音圧レベルは、 中心周波数 $250 \mathrm{~Hz}$ から1kHzにかけて、すべての待合室で50dBを越え ている。

次にインパルス応答の測定を行い、 $T_{20}$ を算出する。測定に用いる 音源信号は、スタッフの医療行為や利用者への影譬が小さいよう、 可能な限りエネルギーの小さな音源を用いる必要がある。そこで、

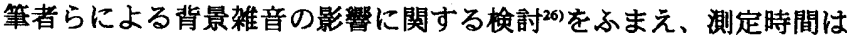

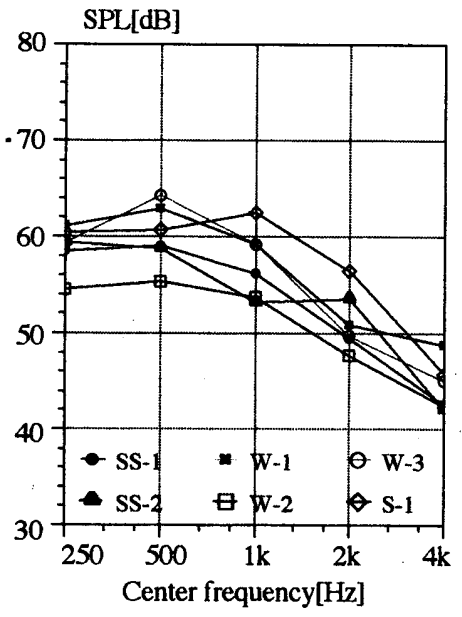

図7＼cjkstart各待合室におけるオクターブバンド 音圧レベル

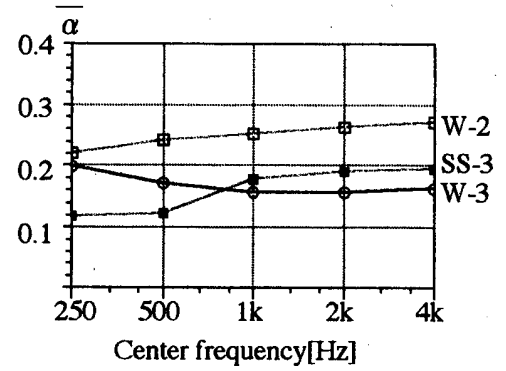

図9 W-2，W-3，SS-3における $\bar{\alpha}$
表9 調查对象待合室の容積・表面積

\begin{tabular}{|l|cl|}
\hline & 容積 $\left(\mathrm{m}^{3}\right)$ & 表面積 $\left(\mathrm{m}^{2}\right)$ \\
\hline W-2 & 159.9 & 209.6 \\
W-3 & 252.9 & 314.9 \\
SS-3 & 223.2 & 263.0 \\
\hline
\end{tabular}

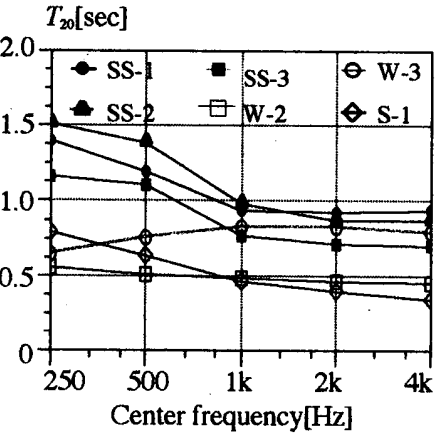

図8 各待合室における $T_{20}$ の周波数特性

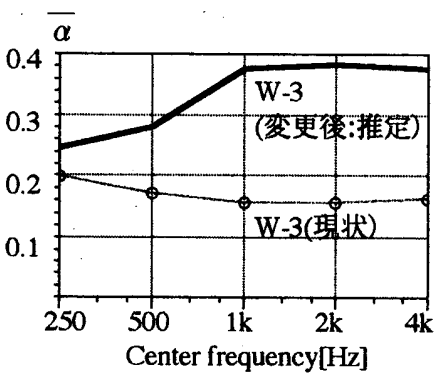

図10 W-3において天井仕上げ材を 岩綿吸音板に変更した場合に 推定される

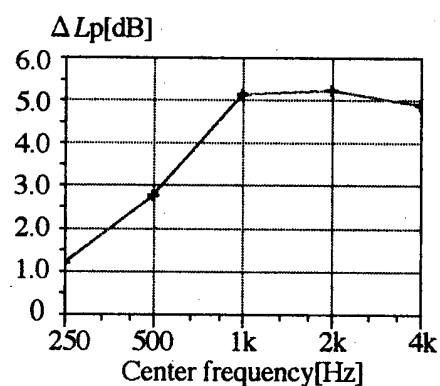

図11 W-3の天井仕上げ材が岩綿吸音板と 化粧石高ボードの場合の $\Delta L \mathrm{p}$

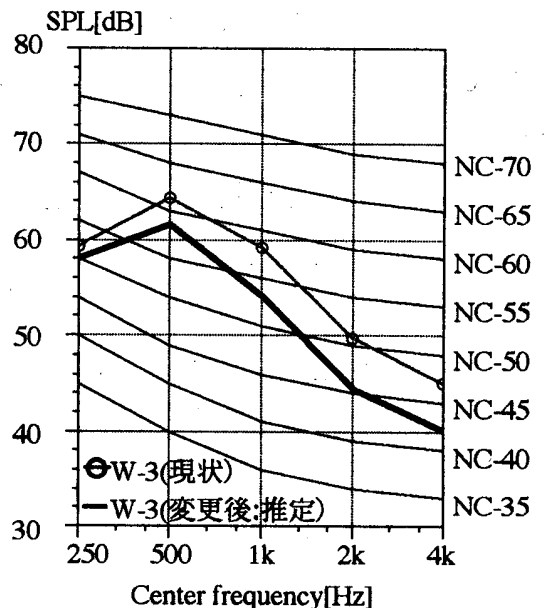

図12 W-3において天井仕上げ材を 岩綿吸音板に変更した場合に 推定されるNC曲線 
原則として利用者が在室しない時間とする。なお、図1に示す調査 対象のうち、W-1は通常の診療時間外も救急外来の待合として使用 され、利用者が在室しない時間带はなく、図 2 に示す通り、 $L_{\text {Aeq, } 13 \mathrm{mi}}$ は夜間でも50dB付近より下がらない。このことから、インパルス店 答の测定はW-1を除く待合室6室で行なう。

図 1 に音源位置 $S$ （床上 $1.2 \mathrm{~m}$ ）、及び受音位置 $\mathrm{R}_{1}$ を示す。音源位置 は看護師が肉声による呼び出しを行う位置を想定し、受音位直は座 席を代表する位置として4点から8点を選択、音源には12面体スピー 力を用い、M系列の次数や同期加算回数は、暗騥音の影響を考虑し 適宜設定する。各室の境界条件は、表3に示すように、天井仕上げ 材はW-3が化䊒石膏ボードで他の待合室は岩綿吸音板、壁材、床材 はそれぞれ吸音率の低い材である。

\section{3 天井仕上げ材の变更による音環境の改善効果}

測定された6室の $T_{20}$ の周波数特性を図8に示す。W-3において、中 心周波数 $250 \mathrm{~Hz}$ から $2 \mathrm{kHz}$ にかけてT $T_{20}$ が長くなるが、他の5室では高 周波数域ほど短くなる。䌇いて、W-3、W-2、SS-3における $T_{20}$ より 算出した平均吸音率（以下、 $\bar{\alpha}$ と表す）を図9に示す。この際、W-3 はすべてのドアを閉じた場合を仮定する。W-2とSS-3は、図1に示す 点線を、それぞれ室の境界とみなし、吸音率1.0として取り扱った。 表9に、この場合の室容積・室表面積を示す。

図9で、W-3のみ中心周波数 $250 \mathrm{~Hz}$ か $2 \mathrm{kHz}$ にかけて $\bar{\alpha}$ が低くな る。これは、天井仕上げ材の吸音性能の違いの影響であると推測さ れる。

次に、W-3の天井仕上げ材の化栍石槀ボードを岩綿吸音板に変更 した場合に推定される $\bar{\alpha}$ を、現状の $\bar{\alpha}$ と合わせて図10に示す。な お、岩綿吸音板と化栍石高ボードの吸音率は文献 ${ }^{27} の$ 残響室法吸音 率を用いる。推定される $\bar{\alpha}$ は、中心周波数 $250 \mathrm{~Hz}$ か $2 \mathrm{kHz}$ にかけて 高くなっており、図9のSS-3やW-2の $\alpha$ と同様の傾向となる。

続いて、図10に示す $\bar{\alpha}$ を用い、完全桩散音場を仮定し文献 ${ }^{28)}$ を参 考に、W-3の音圧レベル(以下、Lpと表す) を算定する。図11に、天 井仕上げ材が岩綿吸音板之化粧石腷ボードの場合のLPの差（以下、 $\Delta L \mathrm{p}$ 表す）を示す。W-3において天井仕上げ材を化粧石高ボード から岩綿吸音板に変更した場合、Lpは、 $500 \mathrm{~Hz}$ で約 $3 \mathrm{~dB} 、 1 \mathrm{kHz}$ から $4 \mathrm{kHz}$ では約 $5 \mathrm{~dB}$ 程度低減すると推定される。

さらに、W-3の現状のNC曲線と、W-3から図11の $\Delta L \mathrm{p}$ を減じた NC曲線を、図12に示す。完全拡散を仮定した単純な試算ではある か゚、NC值29 で1等級向上すると推定される。

また、オクターブバンドレベルの測定值にA特性の補正值を加え 全帯域の音圧レベルを試算すると、周波数重みつき騒音レベルは、 W-3の現状で62.3dB、岩綿吸音板への変更で $60.3 \mathrm{~dB}$ となり、 $2 \mathrm{~dB}$ 程度 の改善効果が推定される。

\section{5. 待合室の音環境に関する問題点と考察}

\section{1 評価手法の確立}

多数の人が出入りし、その利用者が同時に騒音の発生者となるよ うな、公共公益施設の室内における変動騒音の許容值や目標值は明 確に示されていない。このため本研究では、2.2において、騒音に係 る環境基準の改訂の基礎となった、騒音影響に関する室内指針と、 待合室の测定值とを比較した。その結果、本研究で測定を行った全
ての待合室で、指針の基準値を上回っていた。しかし、騒音に係る 環境基準では、基本的に室内に存在する音については考慮されてお らず、この比較結果より単純に評価することは難しい。さらに、図2 に示すとおり、䭷音レベルの時間変動は診療時間に関連した待合室 の利用時間帯と関係しており、測定時間の区分についても検討の余 地がある。今後アンケート調查や駩音レベルの測定等多くの研究が 行われ、病院の待合室における音環境の評価手法の確立が望まれ る。

また、建筑音響的な対策を行う際に必要となる、残響時間その他 の音響指標についても目標となる情報がほとんど無い。4.1に示した ように、以前より吸音材の使用が推奖されているにも関わらず、今 回文献調查した病院・医院では半数以上が天井仕上げ材に吸音率の 低い材を使用していた。これは、音響指標の許容値や指針值が定め られていないことも原因の一端と考えられる。これらを定める研究 推進のため、各種音響指標を算出できるインパルス応答を様々な待 合室で測定し、基礎的資料を得ることが必要であろう。

\section{2 測定手法の確立}

待合室内の騒音レベルの時間変動を把握するうえで、連続測定が 重要である。図2のW-2、W-3、SS-2では、尽間の $L_{\text {A } 0 \text {, } 15 \text { min }}$ の变動が日 によって異なる場合が確認されており、待合室の利用時間が異なる 場合を考慮した、二日以上の連続測定が必要であると考える。しか し、長時間の連続測定を行う際の受音位置は、利用者やスタッフの 動線上を避ける必要があり、また、放送の呼び出し音の直接的な影 響を避けるためには、天井面のスピーカが設置された位置に対して も考慮する必要がある。また、改善を検討するにあたり、各音の騷 音レベルの情報は重要であるが、待合室における測定はSN比の確保 が困難なうえに、音の騒音レベルのばらつきも大きく、測定手法の 検討が必要である。さらに、「患者さん達の会話」のように発生回 数の把握が困難な音も存在する。

インパルス応答の測定に関しては、図2のW-1のように、夜間でも $L_{\text {A }, 15 \min }$ が50dB付近より下がらない待合室もある。一方、スタッフの 医療行為や利用者への影響を考慮すると、測定に用いる音源信号は 可能な限り低エネルギーとする必要がある。また、同期加算による SN比の向上を行うとしても、多数の人が使用する公共公益施設の室 内空間では、系の時変性の影響も大きいと考えられ、時間效率の良 い測定が望ましい。従って、測定誤差の定量化、測定精度に関する 検討をふまえた测定手法の確立が求められる。また、音源・受音点 の設置位置についても、今後検討が必要であろう。

5.3 利用者・スタッフの評価からみた音環境に関する考察

利用者の音環境の評価は、 $L_{\mathrm{Aac}}$ が高いと評価が低くなる傾向がみら れ、 $\chi^{2}$ 検定より、 $L_{\text {Aeq }}$ が $60 \mathrm{~dB}$ 付近で評価に差があると判断したこと を3.3で示した。騒音レベルの高い待合室では、騒音レベルを下げる ことが、利用者の待合室の音環境の評価の向上につながると考えら れる。また、今回の調査では $L_{\text {Aeq }}$ が $50 \mathrm{~dB}$ を下回る時間帯がないため、 $L_{\text {An }}$ の低い待合室の評価にういては今後明らかにしたい。

また、各音に対するうるささに関する評洒は、利用者・スタッフ 共に、利用者から発せられる声をうるさいと回答する割合が高い。 また、利用者とスタッフのアンケート回答結果を比較すると、回収 数や回答時間の違いを含めての結果ではあるが、各音に対してうる 
さいと回答する割合は、すべての音で利用者に比べスタッフが多 く、 $\chi^{2}$ 検定で、評価に差があると判断した。前揭の山田らによる病 棵のアンケート調查9でも、患者に比べ看護師の方が各音に対し、気 になると回答する割合が多いことが報告されている。病院のアンケ 一ト調査で、スタッフのほうが利用者よりも厳しい判断をする傾向 があるのかは現状では明らかではないが、スタッフの労働環境の向 上は、結果として利用者の医療サービス向上と結びつくと予測され るため、利用者・スタッフ双方の評価に着目することも必要であろ う。

\section{4 対策手法に関する考察}

本報では、建築音響的な对策手法の一端として、天井の化粧石亳 ボードから岩綿吸音板への変更が、NC值の一等級向上、また、騒音 レペルで2dB程度の改善効果をもたらすことを示した。この効果は 待合室の $L_{\text {Aeq,15min }}$ に影響していると思われる。しかし、天井に吸音材 を用いているW-2においても、殓療時間 $L_{\text {A0q, } 15 \min }$ は $50 \mathrm{~dB}$ 越え $60 \mathrm{~dB}$ 付 近まで上がる。そこで、建築音響的な対策の他に、運営的な対策、 建築計画的な対策などが考えられる。

運営的な对策には、呼び出し音量の調節や、利用者・スタッフを 对象とした音環境への意識向上に対する啓蒙活動などが挙げられ る。建築計画的な対策には、音の遮音計画や空間の分離などが考え られ、 $L_{\text {Amax }}$ が高く利用者やスタッフがうるさいと回答する割合の多 かった「子供の声」への対処として、子供と付添人の専用待ちスペ 一スの確保などが考えられる。また、近年メディアでは、待合室内 での音に関する利用者へのプライバシー配慮の問題を取り上げてい

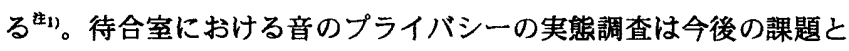
するが、利用者のプライバシーを考慮した場合、問診や説明は他人 に内容が聞かれない場所で行うなどの、建築計画的な対策が必要で あろう。

\section{6. まとめ}

本研究では、病院の待合室における音環境の実態を把握するた め、騒音レベルの連続測定を行い、利用者とスタッフに対するアン ケート調查を行った。また、建策音響的な対策手法の一端として、 インパルス応答の測定結果より算出される $T_{20}$ を用い、待合室の天井 仕上げ材による建築音響特性の変化について定量的な検討を行っ た。主な結果を以下に示す。

(1)待合室の $L_{\text {A aq, } 15 \text { min }}$ の変動は、室の利用時間帯との関係が大きい。

(2)利用者、スタッフ共に、利用者から発せられる声を、うるさいと 回答する割合が、他の音と比較して高い。

(3)利用者の音環境の評価は、 $L_{\text {Aeq }}$ が高いと評価が低くなる傾向がみ られ、 $\chi^{2}$ 検定より、 $L_{\text {Aoq }}$ が $60 \mathrm{~dB}$ 付近で評価に差があると判断した。 (4) $T_{20}$ より算出した $\alpha$ を用い、天井仕上げ材を化精石膏ボードから岩 綿吸音板に变更した場合の L p の低減を推定し、天井の吸音仕上げ材 の勀果を示した。

また、待合室の音環境の評価手法及び測定手法について、それぞ れの問題点と、手法の確立が求められることを示した。さらに、建 築音響的な対策以外の対策手法について考察した。これらの効果の 検討と、それらをふまえた良い待合室モデルの提案については、今 後の課題としたい。
謝辟本研究の一部は、2001年度日本建築学会九州支部研究助成金によって 行った。また、本研究を進めるにあたりアンケート作成にご助言いただいた 九州女子大学岡俊江教授、調查に参加した大分大学卒論生、また調查にご協 カいただいた病院関俰者各位に記して謝意を表す。

注

1)近年メディアで取り上げられた問題として、待合室で大勢人がいる前で 「今日はどこが悪いのですか」と閩くこと（毎日新闑東京夕刊:「今週の異議 あり!病院でのプライバシー」，2002.9.26）、他の利用者が近くにいる受付 空口での説明（朝日新闑朝刊:テーマ特集「患者のプライバシー」， 2001.11.22) などがある。

\section{考考文献}

1)厚生省:「厚生白書」，1995, 第 1 編第1部第 1 章第2節

2)厚生省: 厚生白書」，1997，第1編第1部第5章参考2

3)伊藤誠，小潼一正，河口豊，長澤泰:「新建築学大系31 病院の設計 第二版」， 彰国社, p.49, 2000

4)吉武泰水, 田口正生: ‘建築学大系35 病院第二版」，彰国社, p.307, 1963 5)野村みどり 編 ほか13名:「バリアフリーの生活環境論 第2版」，医蔽桠出 版株式会社, pp.239-240, 1997.5

6)伊藤諴，小獍一正，河口豊，長澤泰:前揭「新建築学大系31 病院の設計 第二 版」, 彰国社, p. 143,2000

7)長澤泰，鈴木毅，山下哲郎:「患者の行動之認知を通してみた病院外来の考察， Hospital Geographyに関する研究1」，、日本建築学会計画系論文集第452号， p.81, 1993.10

8)Sonoko Kuwano, Teruo Yamasaki, Miho Yamauchi, Keiko Okazawa, Yoko Sakuramoto, Harumi Matsumoto, Micho Terada, Yumi Iguchi, Noriko Itoh: 「Sound environment in a hospital - A case study $\rfloor$, Journal of INCE/J, Vol.24, No.4, pp.258-267, 2000

9)山田由紀子，小室克夫，中山茂樹，小久保隆之、櫻井祐介:「病院における蜸音

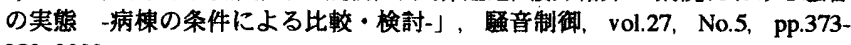
382,2003

10)山田由紀子，平尾善裕:「病院内の騷音に関する基磁的研究 - その1 病院内

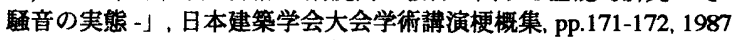

11)上原和夫:「掼しの音環境デザイン」，病院58巻9号, pp.840-842, 1999.9

12)中央環境審榙会: 「騒音の評価手法の在り方について(答申)」，1998.5

13)婹境基本法 第二章 猓境の保全に関する基本的施策 第三節 環境基淮 第十六条

14)矢野隆，五十㞒寿一，加来治郎，金子暂也，神田一伸，桑野園子，新居洋子，佐 藤整身，㾏美智子，山田一郎，吉野泰子:「社会調査に用いる騒音のうるささの 標準尺度」, 日本音䇺学会講演論文集, pp.789-790, 2001.3

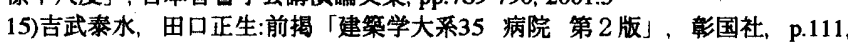
1963

16)医院建築編集委員会: 「医院建榮」，No.15, 彰国社, 1995 17)医院建築編集委員会: 「医院建築」，No.16，乹国社，1996 18)医院建築編集委員会:「医院建慜」，No.17，影国社，1997 19)医院建築編集委員会:「医院建築」，No.18, 乹国社, 1998 20)医院建榮編集委員会:「医院建築」，No.19，彰国社，1999 21)医院建䓩編集委員会:「医院建䓩」，No.20，彰国社，2000 22)医院建築編集委員会:「医院建榮」，No.21，彰国社，2001 23)医院建築編集委員会:「医院建留」，No.22，彰国社，2002 24)医院建築編集委員会:「医院建築」，No.23，彰国社，2003 25)ISO 3382:Measurement of the reverberation time of rooms with reference to other acoustical parameters, 1997

26)内之浦祐樹，大鶴徽、富来礼次，山本みどり:「「背景雑音に起因する室内音響 インパルス応答の測定誤差」、日本音繁学会建築音蠁研究会, 資料番号 AA2003-35, 2003.11

27)日本建築学会編:「音整材料の特性と選定」，p.98，1997

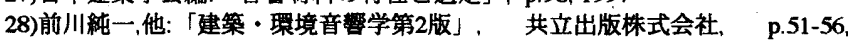
2000.9

29)Leo L. Beranek: 「Revised Criteria for Noise in Buildings」, Noise Control 3, No.1, pp.19-27, 1957

（2004年 2 月 9 日原稿受理，2004年 6 月 17 日採用決定） 